Cite this: Chem. Commun., 2014, 50, 5455

Received 28th January 2014, Accepted 13th March 2014

DOI: $10.1039 / \mathrm{c} 4 \mathrm{cc} 00762 \mathrm{j}$

www.rsc.org/chemcomm

\section{Fast responding and selective near-IR Bodipy dye for hydrogen sulfide sensing $\dagger$}

\author{
Tugba Ozdemir, ${ }^{a}$ Fazli Sozmen, ${ }^{\mathrm{a}}$ Sevcan Mamur, ${ }^{\mathrm{b}}$ Turgay Tekinay $^{\mathrm{b}}$ and \\ Engin U. Akkaya*ac
}

\begin{abstract}
A Bodipy based, highly selective probe for hydrogen sulfide has been designed, synthesized and demonstrated to detect $\mathrm{H}_{2} \mathrm{~S}$ in living cells. In this design, the reduction of two arylazido groups change the charge transfer characteristics of the 3,5-distyryl substituents on the Bodipy core, producing a $20 \mathrm{~nm}$ bathochromic spectral shift in the absorption band, and quenching of the emission by $\mathbf{8 5 \%}$ compared to the original intensity, through photoinduced electron transfer.
\end{abstract}

Hydrogen sulfide $\left(\mathrm{H}_{2} \mathrm{~S}\right)$ has a characteristic repulsive odor of rotten eggs, and plays crucial roles in biological processes; as a result, many groups worldwide are interested in potential agents that will allow its real-time monitoring. ${ }^{1}$ Like the other two gaseous signaling molecules, carbon monoxide $(\mathrm{CO})^{2}$ and nitric oxide (NO), ${ }^{3}$ hydrogen sulfide is a biosynthetic gasotransmitter. These small gaseous molecules are different from the other messenger molecules regarding their production and function. Furthermore, because of their small size and charge neutrality, they can easily pass through the cellular membranes without affecting any cell signaling response. ${ }^{4}$ The important roles of $\mathrm{H}_{2} \mathrm{~S}$ in many metabolic processes, such as cardiovascular protection, neuroprotective effect, arrangement of cell growth, calcium homeostasis and regulation of neurotransmission are well established in the literature. ${ }^{5}$

$\mathrm{H}_{2} \mathrm{~S}$ is an example of reactive sulfur species, such as thiols, $S$-nitrosothiols, sulfenic acids and sulfite, produced enzymatically from cysteine in a series of reactions, mainly catalyzed by two pyridoxal $5^{\prime}$-phosphate-dependent enzymes, cystathionine $\beta$-synthase (CBS) and cystathionine $\gamma$-lyase (CSE) and independently from pyridoxal $5^{\prime}$-phosphate by another enzyme, 3-mercaptopyruvate sulfur transferase (3MST). ${ }^{6}$ Also, elemental sulfur is another endogenous $\mathrm{H}_{2} \mathrm{~S}$ source. ${ }^{7}$

\footnotetext{
${ }^{a}$ UNAM-National Nanotechnology Research Center, Bilkent University, 06800 Ankara, Turkey

${ }^{b}$ Life Sciences Practice and Research Center, Gazi University, 06500 Ankara, Turkey

${ }^{c}$ Department of Chemistry, Bilkent University, 06800 Ankara, Turkey

$\dagger$ Electronic supplementary information (ESI) available: Experimental procedures, structural proofs. See DOI: 10.1039/c4cc00762j
}

Biological imaging probes working in the near-IR region of the spectrum have attracted considerable attention in recent years, since the light used for excitation causes much less photodamage to cells compared to ultraviolet or visible light used in excitation of other probes. In addition, with near IR probes, cell autofluorescence is not an issue. On the other hand, Bodipy dyes, which are difluoroboron-chelated dipyrromethene derivatives, seem to be very good choices for designing novel $\mathrm{H}_{2} \mathrm{~S}$ probes due to their desirable properties, such as high quantum yields, chemical and photochemical stability, high molar absorption coefficients, and the fact that they allow straightforward access to near-IR emitting derivatives (Scheme 1). ${ }^{8}$

In this work, the Knoevenagel type chemistry has been used to obtain a near-IR emissive Bodipy derivative 1 with extended conjugation. Initially, we synthesized Bodipy $\mathbf{5}$ having three triethyleneglycol groups. To that end, compounds $\mathbf{3}$ and $\mathbf{4}$ were prepared according to the reports in the literature. Then Bodipy 5 was obtained by the reaction of aldehyde 4 and 3-ethyl-2,4dimethylpyrrole. Finally, following recently established protocols, the condensation reaction of $p$-azidobenzaldehyde 3 yielded the probe $1\left(\Phi_{\mathrm{f}}=0.38\right.$, cresyl violet in ethanol as a reference dye) in the analytically pure state following chromatographic purification. This reaction not only allowed the formation of the target probe in good yields, but also shifted emission and absorption wavelengths of the probe to the nearIR region.

$\mathrm{H}_{2} \mathrm{~S}$ probes functioning through the reduction of azido groups to amines are available in the literature. ${ }^{9}$ However, most of them do not respond fast enough. On the other hand, the probe proposed in this study (compound 1) responds to $\mathrm{H}_{2} \mathrm{~S}$ with no time delay, practically immediately as the reagents are mixed.

Upon titration of probe 1 with various concentrations of $\mathrm{Na}_{2} \mathrm{~S}$ at room temperature in the acetonitrile-buffer mixture (20 mM HEPES $/ \mathrm{CH}_{3} \mathrm{CN}, 40: 60$, v/v, $\mathrm{pH}=7.20,25{ }^{\circ} \mathrm{C}$ ), a red shift of about $20 \mathrm{~nm}$ was observed in the electronic absorption spectrum (Fig. 1a); the color change was easily noticeable with 
<smiles>Cc1ccc(B(O)O)cc1C=O</smiles>
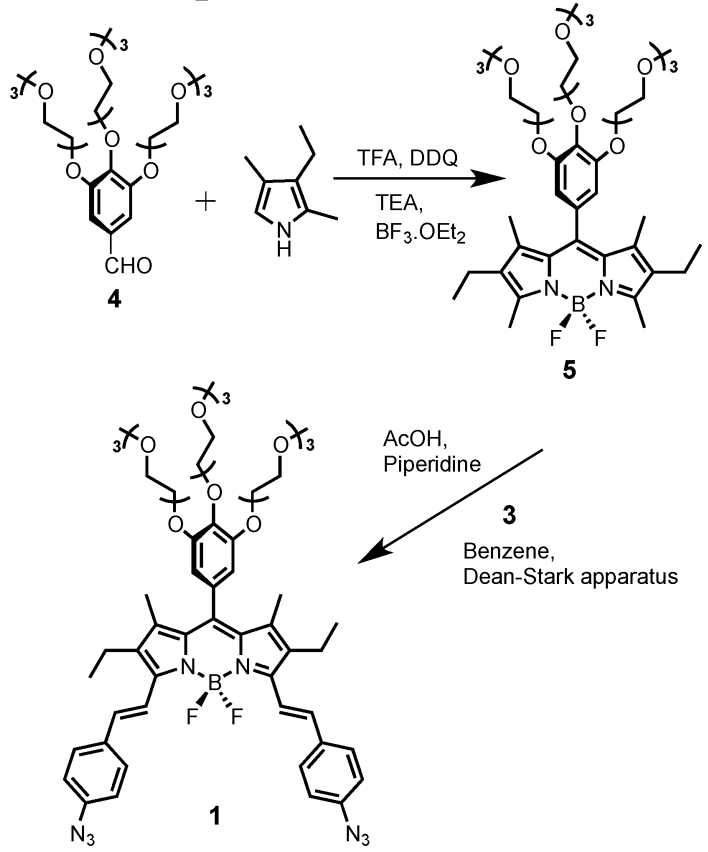

Scheme 1 Synthesis of target probe 1.
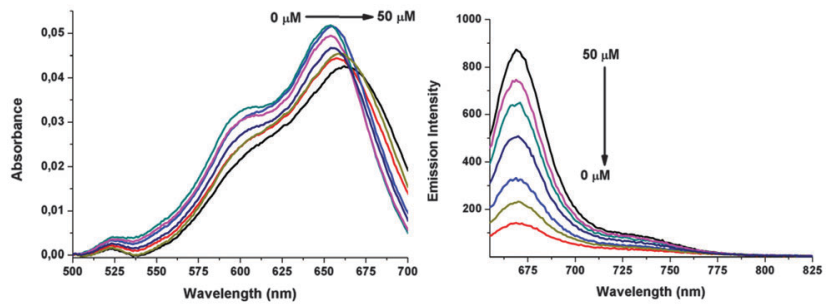

Fig. 1 Absorption and emission spectra of $1(2.0 \mu \mathrm{M})$ in $20 \mathrm{mM}$ HEPES : $\mathrm{CH}_{3} \mathrm{CN}\left(40: 60, \mathrm{v} / \mathrm{v}, \mathrm{pH}=7.20,25^{\circ} \mathrm{C}\right)$ in increasing $\mathrm{Na}_{2} \mathrm{~S}$ concentrations. Excitation wavelength is $650 \mathrm{~nm}$. Experiments were done in triplicate.

the naked eye. The actual ratio of $\mathrm{S}^{2-} / \mathrm{HS}^{-} \mathrm{H}_{2} \mathrm{~S}$ concentrations (speciation) is dictated by the $\mathrm{pH}$ of the buffer.

As shown in the fluorescence spectra (Fig. 1b), the emission of probe 1 was quenched upon increasing $\mathrm{Na}_{2} \mathrm{~S}$ concentrations at room temperature in $20 \mathrm{mM} \mathrm{HEPES} / \mathrm{CH}_{3} \mathrm{CN}$ solutions $\left(40: 60, \mathrm{v} / \mathrm{v}, \mathrm{pH}=7.20,25{ }^{\circ} \mathrm{C}\right)$. The detection limit was determined (ESI $\dagger$ ) to be $0.34 \mu \mathrm{M}$.

The reduction of the azido group to the amine group (mechanism presented in the ESI $\dagger$ ) provides an alternative excited state process (photoinduced electron transfer, PET), which is responsible for quenching of the fluorescence emission.

The selectivity of probe $\mathbf{1}$ for the sulfide species was also investigated. To that end, fluorescence and electronic absorption spectral data were collected for other reactive sulfur species (RSS), reactive oxygen species (ROS) and reactive nitrogen species (RNS). Emission data provide clear evidence that
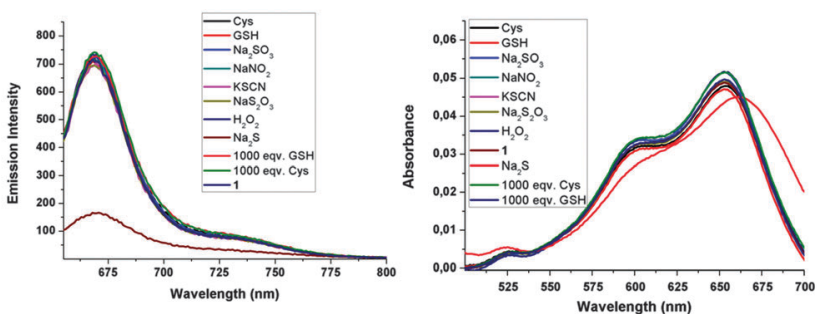

Fig. 2 Absorption and emission spectra of probe $1(2.0 \mu \mathrm{M})$ in $20 \mathrm{mM}$ HEPES: $\mathrm{CH}_{3} \mathrm{CN}\left(40: 60, \mathrm{v} / \mathrm{v}, \mathrm{pH}=7.20,25^{\circ} \mathrm{C}\right)$ in absence and presence of various anions. Added $\mathrm{Na}_{2} \mathrm{~S}$ concentration is $50 \mu \mathrm{M}$ and anion concentrations were $100 \mu \mathrm{M}$. Excitation wavelength is $650 \mathrm{~nm}$. Experiments were done in triplicate.

probe 1 offers very good selectivity for sulfide ions (Fig. 2a). No other species was able to reduce the two azide groups to amine groups; as a result no changes in the fluorescence emission spectra were observed. Competition experiments in the presence of a number of competing anions were also conducted (ESI $\dagger$ ), again corroborating the selectivity of the probe. The electronic absorption spectra were unchanged as well. We also note that 1000 equivalents of glutathione or cysteine do not cause any changes in the emission intensity or absorbance spectrum of probe 1 (Fig. 2).

An NMR titration experiment was performed in order to investigate the changes in the chemical shifts of the aromatic protons during the reduction. Fig. 3 shows the partial ${ }^{1} \mathrm{H}$ NMR spectra of the probe before (Fig. 3a) and after (Fig. 3b) $\mathrm{Na}_{2} \mathrm{~S}$ addition in $\mathrm{CD}_{3} \mathrm{CN}$. The NMR spectrum clearly shows that all the aromatic protons of probe $\mathbf{1}$ were shifted upfield due to the formation of the electron donor amine group as expected. In addition, mass spectral (HRMS, ESI $\dagger$ ) data following sulfide treatment of probe $\mathbf{1}$, supports our structure assignment for the reduction product.

We also wanted to demonstrate the utility of probe 1 in living cells (Fig. 4). Human breast adenocarcinoma cells (MCF-7) were grown to confluence at $37{ }^{\circ} \mathrm{C}$ under $5 \% \mathrm{CO}_{2}$ in Dulbecco's Modified Eagle Serum (DMEM) containing 1\% penicillin/streptomycin, $10 \%$ fetal bovine serum (FBS) and

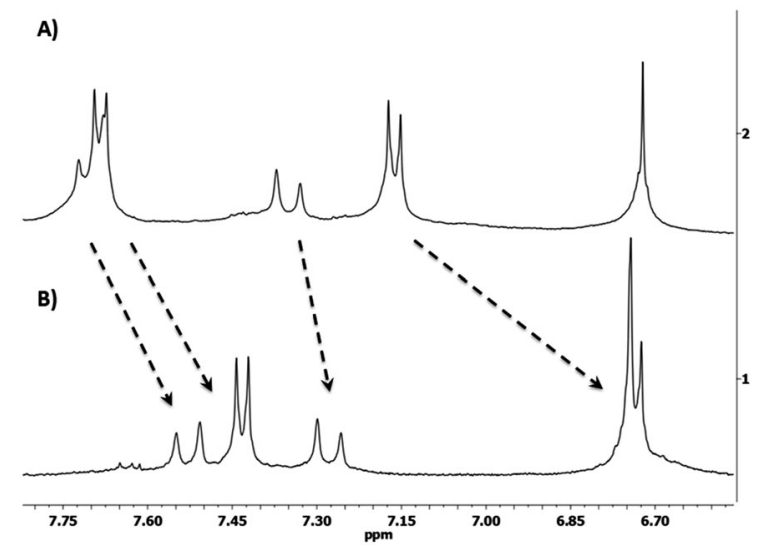

Fig. 3 Stacked partial ${ }^{1} \mathrm{H}-\mathrm{NMR}$ spectra of probe 1 (A) and the same spectrum after the addition of $\mathrm{Na}_{2} \mathrm{~S}(\mathrm{~B})$ in acetonitrile- $\mathrm{D}_{3}$ at $25^{\circ} \mathrm{C}$. 


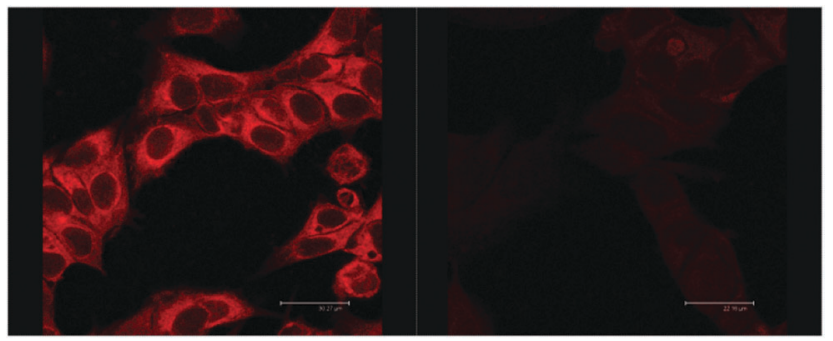

Fig. 4 Confocal microscopy images of showing the $\mathrm{H}_{2} \mathrm{~S}$ response of probe 1 in MCF-7 cells. (left) MCF-7 cells incubated with probe $1(4 \mu \mathrm{M})$ for $30 \mathrm{~min}$ at $37^{\circ} \mathrm{C}$. (right) MCF-7 cells incubated with probe $1(4 \mu \mathrm{M})$ for $2 \mathrm{~h}$, after which 100 equiv. $\mathrm{Na}_{2} \mathrm{~S}$ was added. The cells were imaged after additional incubation for $30 \mathrm{~min}$ at $37^{\circ} \mathrm{C}$.

$2 \mathrm{mM}$ L-glutamine. MCF-7 cells were incubated with $4.0 \mu \mathrm{M}$ probe 1 for $30 \mathrm{~min}$ at $37{ }^{\circ} \mathrm{C}$ and then washed with physiological saline to remove any excess amount of the probe. Under these conditions, confocal microscope imaging shows intense intracellular red fluorescence emission upon excitation at $633 \mathrm{~nm}$. The cells, which were treated with probe 1 , were then incubated with $400 \mu \mathrm{M} \mathrm{Na} \mathrm{N}_{2} \mathrm{~S}$ in HEPES buffer for 2 hours at $37{ }^{\circ} \mathrm{C}$. The quenching of intracellular fluorescence intensity of probe 1 was clearly visible under a microscope for the sulfide treated cells. Again, as noted for the spectroscopic experiments, the quenching seems to be only limited by the duration of incubation; the reaction seems to be very fast. Confocal microscope imaging was performed on a Leica TCS SP2 laser scanning microscope with an oil-immersion $40 \times$ objective lens.

In conclusion, we have developed a sensitive $\mathrm{H}_{2} \mathrm{~S}$ detection probe which operates much faster than the existing $\mathrm{H}_{2} \mathrm{~S}$ probes. The azide based probe 1 responds to the $\mathrm{H}_{2} \mathrm{~S}$ through reduction of two azido groups, resulting in instant quenching of the emission and a noticeable red shift in the absorbance spectrum. The highly selective and sensitive nature of probe $\mathbf{1}$ for $\mathrm{H}_{2} \mathrm{~S}$ over other reactive species demonstrates the potential utility of probe $\mathbf{1}$. Moreover, due to the presence of hydrophilic moieties in its structure, the probe is water soluble and thus appropriate for biological applications. Thus, the added $\mathrm{H}_{2} \mathrm{~S}$ was successfully imaged inside the cells, suggesting the possibility of imaging endogenously produced $\mathrm{H}_{2} \mathrm{~S}$ in real-time and in the near IR region of the spectrum.

\section{Notes and references}

1 W. Xuan, C. Sheng, Y. Cao, W. He and W. Wang, Angew. Chem., Int. $E d$., 2012, 51, 2282; A. P. de Silva, H. Q. N. Gunaratne, T. Gunnlaugsson, A. J. M. Huxley, C. P. McCoy, J. T. Rademacher and T. E. Rice, Chem. Rev., 1997, 97, 1515; P. D. Beer and P. A. Gale, Angew. Chem., Int. Ed., 2001, 40, 486; R. Martinez-Manez and
F. Sancenon, Chem. Rev., 2003, 103, 4419; Y. Qian, J. Karpus, O. Kabil, S.-Y. Zhang, H.-L. Zhu, R. Banerjee, J. Zhao and C. He, Nat. Commun., 2011, 2, 495; J. Zhang, Y.-Q. Sun, J. Liu, Y. Shi and W. Guo, Chem. Commun., 2013, 49, 11305; X. Li, S. Zhang, J. Cao, N. Xie, T. Liu, B. Yang, Q. He and Y. Hu, Chem. Commun., 2013, 49, 8656; X. Qu, C. Li, H. Chen, J. Mack, Z. Guo and Z. Shen, Chem. Commun., 2013, 49, 7510; Y. Qian, L. Zhang, S. Ding, X. Deng, C. He, X. E. Zheng, H.-L. Zhu and J. Zhao, Chem. Sci., 2012, 3, 2920; R. Wang, F. Yu, L. Chen, H. Chen, L. Wang and W. Zhang, Chem. Commun., 2012, 48, 11757; N. Kumar, V. Bhalla and M. Kumar, Coord. Chem. Rev., 2013, 257, 2335.

2 J. E. Clark, P. Naughton, S. Shurey, C. J. Green, T. R. Johnson, B. E. Mann, R. Foresti and R. Motterlini, Circ. Res., 2003, 93, e2; M. Bilban, A. Haschemi, B. Wegiel, B. Y. Chin, O. Wagner and L. E. Otterbein, J. Mol. Med., 2008, 86, 267; F. Amersi, X. D. Shen, D. Anselmo, J. Melinek, S. Iyer, D. J. Southard, M. Katori, H. D. Volk, R. W. Busuttil and R. Buelow, Hepatology, 2002, 35, 815; C. A. Piantadosi, Free Radical Biol. Med., 2008, 45, 562.

3 E. Culotta and D. E. Koshland Jr, Science, 1992, 258, 1862; L. J. Ignarro, G. Cirino, A. Casini and C. Napoli, J. Cardiovasc. Pharmacol., 1999, 34, 879; L. J. Ignarro, Angew. Chem., Int. Ed., 1999, 38, 1882; E. Anggård, Lancet, 1994, 343, 1199.

4 B. L. Predmore, D. J. Lefer and G. Gojon, Antioxid. Redox Signaling, 2012, 17, 119.

5 R. Baskar and J. Bian, Eur. J. Pharmacol., 2011, 656, 5; D. J. Lefer, Proc. Natl. Acad. Sci. U. S. A., 2007, 104, 17907; A. Papapetropoulos, A. Pyriochou, Z. Altaany, G. Yang, A. Marazioti, Z. Zhou, M. G. Jeschke, L. K. Branski, D. N. Herndon, R. Wang and C. Szab, Proc. Natl. Acad. Sci. U. S. A., 2009, 106, 21972; W. A. Pryor, K. N. Houk, C. S. Foote, J. M. Fukuto, L. J. Ignarro, G. L. Squadrito and K. J. A. Davies, Am. J. Physiol.: Regul., Integr. Comp. Physiol., 2006, 291, R491; M. M. Gadalla and S. H. Snyder, J. Neurochem., 2010, 113, 14; O. Kabil and R. Banerjee, J. Biol. Chem., 2010, 285, 21903; C. Mancuso, P. Navarra and P. Preziosi, J. Neurochem., 2010, 113, 563.

6 S. Singh, D. Padovani, R. A. Leslie, T. Chiku and R. Banerjee, J. Biol. Chem., 2009, 284, 22457; T. Chiku, D. Padovani, W. Zhu, S. Singh, V. Vitvitsky and R. Banerjee, J. Biol. Chem., 2009, 284, 11601; N. Shibuya, M. Tanaka, M. Yoshida, Y. Ogasawara, T. Togawa, K. Ishii and H. Kimura, Antioxid. Redox Signaling, 2009, 11, 703.

7 D. G. Searcy and S. H. Lee, J. Exp. Zool., 1998, 282, 310; M. Whiteman and P. K. Moore, J. Cell. Mol. Med., 2009, 13, 488.

8 G. Ulrich, R. Ziessel and A. Harriman, Angew. Chem., Int. Ed., 2008, 47, 1184; R. Ziessel, G. Ulrich and A. Harriman, New J. Chem., 2007, 31, 496; A. Loudet and K. Burgess, Chem. Rev., 2007, 107, 4891; O. Buyukcakir, O. A. Bozdemir, S. Kolemen, S. Erbas and E. U. Akkaya, Org. Lett., 2009, 11, 4644; Z. Kostereli, T. Ozdemir, O. Buyukcakir and E. U. Akkaya, Org. Lett., 2012, 14, 3636; K. Rurack, M. Kollmannsberger and J. Daub, Angew. Chem., Int. Ed., 2001, 40, 385; D. Zhang, Y. Wen, Y. Xiao, G. Yu, Y. Liu and X. Qian, Chem. Commun., 2008, 4777; S. Atilgan, I. Kutuk and T. Ozdemir, Tetrahedron Lett., 2010, 51, 892; X. Qi, S. K. Kim, S. J. Han, L. Xu, A. Y. Jee, H. N. Kim, C. Lee, Y. Kim, M. Lee, S.-J. Kim and J. Yoon, Supramol. Sci., 2009, 21, 455; S. Erbas, A. Gorgulu, M. Kocakusakogullari and E. U. Akkaya, Chem. Commun., 2009, 4956; R. Guliyev, S. Ozturk, Z. Kostereli and E. U. Akkaya, Angew. Chem., Int. Ed., 2011, 50, 9826; O. A. Bozdemir, Y. Cakmak, F. Sozmen, T. Ozdemir, A. Siemiarczuk and E. U. Akkaya, Chem. - Eur. J., 2010, 16, 6346.

9 L. A. Montoya and M. D. Pluth, Chem. Commun., 2012, 48, 4767; A. R. Lippert, E. J. New and C. J. Chang, J. Am. Chem. Soc., 2011, 133, 10078; M. K. Thorson, T. Majtan, J. P. Kraus and A. M. Barrios, Angew. Chem., Int. $E d$., 2013, 52, 1; T. Chen, Y. Zheng, Z. Xu, M. Zhao, Y. Xu and J. Cui, Tetrahedron Lett., 2013, 54, 2980; W. Sun, J. Fan, C. Hu, J. Cao, H. Zhang, X. Xiong, J. Wang, S. Cui, S. Sun and X. Peng, Chem. Commun., 2013, 49, 3890. 